\title{
GW23-e0718 MECHANISM OF INCREASED EXPRESSION OF INFLAMMATORY FACTOR IN ENDOTHELIAL CELLS AS IT IS INCUBATED IN D-GLUCOSE
}

doi:10.1136/heartjnl-2012-302920a.219

Chengbei Yangbin. Department of Gerontology, Union Hospital, Tongji Medical College, Huazhong University of Science and Technology

Objectives To study the mechanism for increased expression of inflammatory factor in endothelial cells as it is incubated in D-glucose.

Methods The human umbilical vein endothelial cells (HUVECs) that isolated from newborn umbilical cord were cultured and verified as vascular endothelial cells by immunohistochemistry in vitro. Passage 2 cells were stimulated by D-glucose with different concentration and time respectively. Levels of ROS were studied with flow cytometry and MCP-1 mRNA expression was assayed by reverse-transcription PCR (RT-PCR).

Results Formation of ROS and transcript of MCP-1 were increased gradually as the HUVECs were incubated by high D-glucose, although there were no significant changes in $5.5 \mathrm{mmol} / \mathrm{l}$ group at different time point. $16.5 \mathrm{mmol} / \mathrm{l}$ and $25.0 \mathrm{mmol} / \mathrm{l}$ glucose significantly increased the formation of ROS within $24 \mathrm{~h}(\mathrm{p}<0.01)$ in cultured HUVECs. The levels of ROS in $25.0 \mathrm{mmol} / \mathrm{l}$ group were higher than that in $16.5 \mathrm{mmol} / \mathrm{l}$ group as the HUVECs were treated for $12 \mathrm{~h}$ $(p<0.05)$. The expression of MCP-1 increased slowly as the HUVECs were exposed to high concentration of glucose. But significant increase of MCP-1 expression were emerged in $25.0 \mathrm{mmol} / 1$ group as compare to $5.5 \mathrm{mmol} / \mathrm{l}$ group within $12 \mathrm{~h}(\mathrm{p}<0.05)$ and $16.5 \mathrm{mmol} / \mathrm{l}$ group within $24 \mathrm{~h}(\mathrm{p}<0.05)$, respectively.

Conclusions HUVECs will produce more ROS and other metabolic products as it incubated in D-glucose, which links the damage and dysfunction of VECs to D-glucose and cytokines around intimae. Reinforced expression of MCP-1 is the important mechanism which leads to the damage and dysfunction of VECs. 